\title{
Multiple Species Comparison of Cardiac Troponin T and Dystrophin: Unravelling the DNA behind Dilated Cardiomyopathy
}

\author{
Jennifer England ${ }^{1}$, Siobhan Loughna ${ }^{1}$ (D) and Catrin Sian Rutland ${ }^{2, *}$ (D) \\ 1 School of Life Sciences, Medical School, Queens Medical Centre, University of Nottingham, \\ Nottingham NG7 2UH, UK; jennifer.england88@gmail.com (J.E.); Siobhan.loughna@nottingham.ac.uk (S.L.) \\ 2 School of Veterinary Medicine and Science, University of Nottingham, Sutton Bonington Campus, \\ Sutton Bonington, Leicestershire LE12 5RD, UK \\ * Correspondence: catrin.rutland@nottingham.ac.uk; Tel.: +44-115-951-6573
}

Received: 21 June 2017; Accepted: 5 July 2017; Published: 7 July 2017

\begin{abstract}
Animals have frequently been used as models for human disorders and mutations. Following advances in genetic testing and treatment options, and the decreasing cost of these technologies in the clinic, mutations in both companion and commercial animals are now being investigated. A recent review highlighted the genes associated with both human and non-human dilated cardiomyopathy. Cardiac troponin $\mathrm{T}$ and dystrophin were observed to be associated with both human and turkey (troponin T) and canine (dystrophin) dilated cardiomyopathies. This review gives an overview of the work carried out in cardiac troponin $\mathrm{T}$ and dystrophin to date in both human and animal dilated cardiomyopathy.
\end{abstract}

Keywords: dilated cardiomyopathy; troponin; dystrophin; mutation; species

\section{Introduction to Cardiomyopathies}

Cardiomyopathies are a group of diseases of the heart muscle that contribute to cardiac dysfunction leading to heart failure [1]. They are associated with a high rate of morbidity and mortality and increased risk of sudden cardiac death. According to the American Heart Association, there are five classifications of cardiomyopathy: dilated cardiomyopathy (DCM), hypertrophic cardiomyopathy (HCM), restrictive cardiomyopathy (RCM), arrhythmogenic right ventricular cardiomyopathy (ARVC), and left ventricular non-compaction (LVNC) [1,2]. HCM in humans is characterized by left and/or right ventricular wall thickening with non-dilation of the ventricles with myocyte disorganization, fibrosis, increased calcium sensitivity, and cardiac arrhythmias [3]. RCM, a rare form of cardiomyopathy, presents with dilated atria, restricted ventricular filling, reduced diastolic volume in the ventricles with occasional fibrosis of the myocardium [4]. Arrhythmogenic right ventricular cardiomyopathy is associated with cardiomyocyte replacement with fibrofatty tissue. This fatty deposition results in obstruction of electrical conduction, thus resulting in arrhythmias [5]. LVNC is characterized by the presence of prominent trabeculae and deep recesses in the ventricular cavity of the mature heart and can coexist with congenital heart defects such as atrial and ventricular septal defects, aortic stenosis and aortic coarctation [6]. These cardiomyopathies are also further subclassified into inherited and acquired diseases. Mutations in sarcomeric proteins have been associated with all of the cardiomyopathies, except for ARVC.

\subsection{Dilated Cardiomyopathy in Humans}

Idiopathic dilated cardiomyopathy has a high incidence of 1 in 250 people and is the most common reason for heart transplants [2]. The DCM phenotype includes dilation of one or both ventricles and 
systolic dysfunction, and is usually associated with congestive heart failure [7,8]. DCM is associated with a range of causes such as familial, environmental, idiopathic, or as part of the progression of other cardiovascular disease [9]. Genetic forms of DCM, which account for $30-50 \%$ of cases, usually result from mutations in genes encoding cytoskeletal and sarcomeric proteins such as myosin heavy chain 7 (MYH7), cardiac muscle troponin T (TNNT2), and Titin (TTN) [10].

\subsection{Dilated Cardiomyopathy in Animals}

Clinical data indicates that DCM accounts for $10 \%$ of cardiac diagnoses in dogs, with cardiovascular disease being the fourth most common cause of canine death [11,12]. In dogs, differing incidence rates in the breeds have indicated that a genetic link may be present. An autosomal link was first suggested in the 1990s [13]. Since then a number of genetic associations have been made throughout the breeds [14]. These have ranged from single gene deletions [15] to splice site and point mutations [16-18]. More recently models and genetic testing in affected dogs has indicated the role of both multiple allele linkage and multiple allele involvement in DCM [19,20].

DCM has been reported in wild turkeys [21], furazolidone-induced DCM captive turkeys [22-24], hypoxia-induced hypoxemia birds [25] and calcium activated turkey models [26]. Roughly $2-5 \%$ of domesticated turkeys get DCM within the first four weeks of hatching [27]. Diet has been shown to play a key role with birds fed a high protein diet twice as likely to suffer death as a result of cardiomyopathy [28], but variations in Troponin T and phospholamban (PLN) have also been linked to DCM $[27,29]$.

Feline DCM clinical outcomes improved rapidly following the discovery that dietary taurine supplementation worked in both naturally acquired and experimental populations [30-33]. Despite this discovery, DCM was still present in the population and investigations into two breeding colonies indicated that a genetic factor was likely [34]. In addition to these species, cattle and chickens also have DCM [35-37].

A recent review highlighted that both cardiac troponin $\mathrm{T}$ and dystrophin mutations play a role in cardiomyopathies in both humans and animals [38]. This review explores the literature to date and the mutation links to DCM for each gene.

\subsection{Expression, Structure, and Function of Cardiac Troponin $T$}

The troponin complex is a multipart protein found in the thin filament of the sarcomere. It is composed of three parts: troponins (Tn) C, I, and T encoded by TNNC, TNNI, and TNNT, respectively [39]. TnC, binds $\mathrm{Ca}^{2+}$ which induces a conformational change to the Tn complex [40]. $\mathrm{TnI}$ is the inhibitory component of the unit. Muscle contraction is powered by the actin-myosin motor, which converts ATP into energy (using ATPase) for a power stroke through each cross-bridge cycle [40]. TnI blocks ATPase activity in a $\mathrm{Ca}^{2+}$ dependent manner.

TnT is essential for structural integrity of the troponin complex, binding tropomyosin (TPM), $\mathrm{TnC}$, and $\mathrm{TnI}$ and is essential for sarcomere assembly and cardiac contractility [41]. When $\mathrm{Ca}^{2+}$ binds to TnC inducing a conformational change to the Tn complex, cTnC binds to cTnI causing it to release cTnT. This lever action moves TPM around the actin filament, thus exposing myosin binding sites on the actin filament.

Three TnT genes exist, slow skeletal TnT (TNNT1), cardiac TnT (TNNT2), and fast skeletal TnT (TNNT3). In addition, alternative RNA splicing adds another dimension of generating multiple isoforms of TnT, a process with is developmentally regulated. Exon 4, exon 5, and exon 13 are alternately spliced, where exon 5 is absent in the adult isoform of cTnT. This exon produces a highly acidic and negatively charged 10 amino acid segment which shows higher $\mathrm{Ca}^{2+}$ sensitivity of the ATPase activity and force production when compared to the adult isoform [42], suggesting not just a structural role, but also a functional one for TnT in the sarcomere.

Understanding the structure of cTnT may elucidate a reason why point mutations cause such devastating effects on the heart. At the N-terminus of cTnT, the first 1-59 amino acid residues are 
enriched with negatively charged residues of glutamine and aspartate [43]. It is a highly variable region, lacking any known protein binding sites, such as actin or tropomyosin [44]. Conversely, the remaining $\mathrm{N}$-terminus, middle portion and C-terminus of the protein are highly conserved and enriched with positively charged residues (Figure 1A,B) [43]. There are two TPM binding domains, one of which is present at the $\mathrm{N}$-terminus (known as $\mathrm{T} 1$ fragment) within residues 98-138 [45]. The T1 sub-fragment is thought to bind to the C-terminus of the TPM in the region where TPM overlaps head to tail to form a continuous TPM filament [46]. Residues 183-204 act as a flexible linker between the T1-fragment and the C-terminus [47]. An actin binding site is present in this linker. The C-terminus of TnT is composed of $\alpha$-helical rings at residues 204-220 (Helix 1) and 226-272 (Helix 2) [47,48]. A second TPM binding domain (T2) is close to the C-terminus, but controversy remains as to its precise location (either at residues $197-239$ or the last 16 residues of the TnT sequence) [45,49-52].
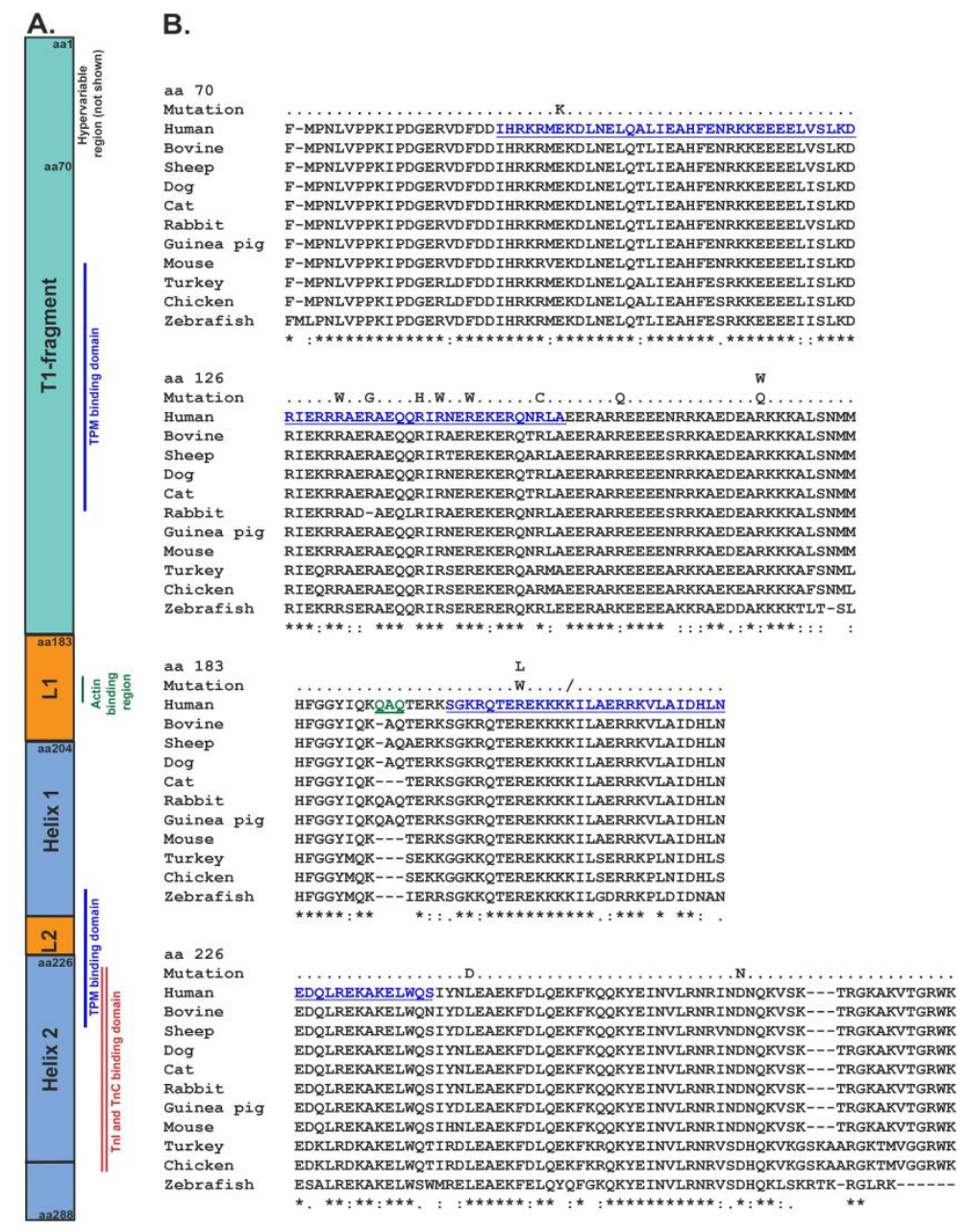

Figure 1. The structure and functional regions of cardiac troponin $\mathrm{T}$ alongside the sequence alignment of the regions. (A) A schematic image showing the structure of the cTnT protein. The first region of the T1-fragment is known as the hypervariable region and is highly unconserved. Different binding domains of other thin filament proteins are highlighted in the schematic, the blue line indicates the tropomyosin binding domain, green the actin binding domain, and red is the troponin I and troponin $\mathrm{C}$ binding domains. L1 and L2 indicate the flexible linkers between helix zone 1 and 2; (B) A multiple species alignment of the cTnT protein in comparison to the regions shown in A. Mutations associated with dilated cardiomyopathy are aligned also. The first 70 amino acids of cTnT have been excluded as no mutations are known in this area. Accession numbers for each species are: human NP_001001430, bovine AF175558, sheep P50751, dog NP_001003012, cat NP_001009347, rabbit A25345, guinea pig NM_001172863, mouse NM_011619, turkey AF274301, chicken NM10013, and zebrafish NP_69085. 


\subsection{Cardiac Troponin T Mutations Relating to Cardiomyopathy in Humans}

Currently, over 90 mutations have been identified in Tn subunits associated with hypertrophic cardiomyopathy, dilated cardiomyopathy, left ventricular non-compaction, and restrictive cardiomyopathy [53,54], with mutations in cTnT believed to have a frequency of 3-6\% in DCM [55]. Mutations in cTnT that have been linked with DCM are listed in Table 1 along with their clinical presentation and known molecular and cellular effects. These mutations are also compared to multiple species for conservation in Figure 1B. Point mutations are most commonly found in the conserved region of the $\mathrm{T} 1$ terminal and the $\mathrm{C}$-terminal of cTnT. Interestingly, no mutations have been found in the N-terminal hypervariable region of cTnT. This may be due to the nature of such a variable region in that it is more tolerable to changes introduced by a single amino acid substitution than an area that is highly conserved would be.

Mutations associated with HCM and RCM generally lead to increased $\mathrm{Ca}^{2+}$ sensitivity in the thin filament [53]. In contrast, decreased $\mathrm{Ca}^{2+}$ sensitivity is commonly observed in mutations in cTnT associated with DCM (R131W, R139H, R141W, R151C, R159Q, R205W, $\Delta$ K210, and K273E) [52,56]. $\mathrm{Lu}$ et al. suggested that the reason one mutation could possibly have such a huge impact on $\mathrm{Ca}^{2+}$ sensitivity was due to an increase in the affinity of cTnT for TPM1 observed for the R141W mutation. The mutation strengthened the integrity of cTnI in the thin filament by stabilizing the interaction between cTnT and TPM, which might allow cTnI to inhibit the thin filament more effectively, leading to $\mathrm{Ca}^{2+}$ desensitization [57]. However, some mutations report no change (R134G) [52], suggesting that $\mathrm{Ca}^{2+}$ sensitivity is a stimulus sufficient to cause DCM, but not essential, or the only cellular mechanism triggering cardiac remodeling observed in DCM.

Table 1. Mutations found in TNNT2 associated with dilated cardiomyopathy, sudden cardiac death (SCD), dilated cardiomyopathy (DCM), hypertrophic cardiomyopathy (HCM), Leiden Muscular Dystrophy (LOVD).

\begin{tabular}{|c|c|c|c|c|}
\hline Mutation/rs ID & Exon & Clinical Presentation/Frequency & Molecular/Cellular Effects & Reference \\
\hline E96K/LOVD\#0030558 & 10 & Familial DCM (age 5 months) & - & {$[58,59]$} \\
\hline $\begin{array}{l}\mathrm{R} 131 \mathrm{~W} / \mathrm{rs} \\
483352833\end{array}$ & 11 & $\begin{array}{l}\text { DCM diagnosed (age 23); SCD (age 16); } \\
\text { heart failure death (age 34) }\end{array}$ & $\begin{array}{l}\text { Enhanced cTnC-cTnI } \\
\text { interaction while decreasing } \\
\text { cTnC-cTnT interactions; } \\
\text { decreased } \mathrm{Ca}^{2+} \text { sensitivity; } \\
\text { decreased ATPase activity }\end{array}$ & {$[56,60,61]$} \\
\hline R134G/45525839 & 11 & $\begin{array}{l}\text { Familial DCM (age 6) and heart transplant } \\
\text { (by age } 7 \text { ) }\end{array}$ & $\begin{array}{l}\text { increased maximal force } \\
\text { development; no change in } \\
\mathrm{Ca}^{2+} \text { sensitivity }\end{array}$ & {$[52,58,60,62]$} \\
\hline $\mathrm{R} 139 \mathrm{H}$ & 11 & Late onset DCM (age 70) & $\begin{array}{l}\text { Decreased } \mathrm{Ca}^{2+} \text { sensitivity } \\
\text { and maximal force } \\
\text { development }\end{array}$ & [63] \\
\hline $\begin{array}{l}\text { R141W/rs } 7315379 \\
\text { and rs } 74315380\end{array}$ & 11 & $\begin{array}{l}\text { Idiopathic DCM and Familial DCM; does } \\
\text { not cause SCD }\end{array}$ & $\begin{array}{l}\text { Increased affinity of cTnT to } \\
\text { TPM; decreased } \mathrm{Ca}^{2+} \\
\text { sensitivity; decreased } \\
\text { ATPase activity }\end{array}$ & {$[56,62,64]$} \\
\hline $\begin{array}{l}\mathrm{R} 144 \mathrm{~W} / \mathrm{rs} \\
483352832\end{array}$ & 11 & $\begin{array}{l}\text { Familial DCM with history of SCD; } \\
\text { variability in severity within the family }\end{array}$ & Decreased ATPase activity & {$[65]$} \\
\hline $\mathrm{R} 151 \mathrm{C} / \mathrm{rs} 45608937$ & 11 & Idiopathic DCM & Decreased $\mathrm{Ca}^{2+}$ sensitivity & {$[52,60]$} \\
\hline R159Q/rs 45501500 & 12 & Idiopathic DCM & Decreased $\mathrm{Ca}^{2+}$ sensitivity & {$[52,60]$} \\
\hline A171S & 12 & Familial DCM and SCD (>age 20) & - & {$[66,67]$} \\
\hline R173G & 12 & $\begin{array}{l}\text { Familial DCM. Diagnosed at birth with } \\
\text { dilated left ventricles }(n=2) \text {. } \\
\text { Asymptomatic maternal uncle (age } 45) \text { and } \\
\text { his cousin with mildly dilated left ventricle. }\end{array}$ & - & [68] \\
\hline R173W & 12 & $\begin{array}{l}\text { Familial DCM with dilated left ventricle, } \\
\text { decreased ejection fraction and heart } \\
\text { transplant (age 14) }\end{array}$ & $\begin{array}{l}\text { Altered } \mathrm{Ca}^{2+} \text { regulation; } \\
\text { decreased contractility; } \\
\text { sarcomere disorganization }\end{array}$ & {$[69,70]$} \\
\hline R173Q & 12 & $\begin{array}{l}\text { Dilated left ventricle at birth; SCD due to } \\
\text { arrhythmia; asymptomatic dilated } \\
\text { left ventricle }\end{array}$ & - & [68] \\
\hline
\end{tabular}


Table 1. Cont.

\begin{tabular}{|c|c|c|c|c|}
\hline Mutation/rs ID & Exon & Clinical Presentation/Frequency & Molecular/Cellular Effects & Reference \\
\hline $\begin{array}{c}\mathrm{R} 205 \mathrm{~W} / \mathrm{rs} \\
45586240\end{array}$ & 14 & Idiopathic DCM (6 months) & Decreased $\mathrm{Ca}^{2+}$ sensitivity & {$[52,60]$} \\
\hline $\begin{array}{l}\mathrm{R} 205 \mathrm{~L} / \mathrm{rs} \\
121964860\end{array}$ & 14 & Familial DCM & $\begin{array}{l}\text { Impaired cTnI-cTnC and } \\
\text { cTnC-cTnT interactions; } \\
\text { decreased ATPase activity }\end{array}$ & {$[56,61]$} \\
\hline $\begin{array}{l}\Delta \mathrm{K} 210 / \mathrm{rs} \\
121964859\end{array}$ & 14 & Familial DCM; high incidence of SCD & $\begin{array}{l}\text { Decreased } \mathrm{Ca}^{2+} \text { sensitivity, } \\
\text { maximal force and ATPase } \\
\text { activity; impaired cTnC-cTnI } \\
\text { and cTnC-cTnT interactions }\end{array}$ & {$[61,71-74]$} \\
\hline E244D/rs 45466197 & 15 & $\begin{array}{l}\text { Familial DCM, previously associated with } \\
\text { HCM; idiopathic DCM (age 7), heart } \\
\text { transplant required; mutation seen with } \\
\text { A277V mutation in TPM1. Identified } \\
\text { in one family. }\end{array}$ & - & {$[52,58,75]$} \\
\hline $\begin{array}{l}\mathrm{D} 270 \mathrm{~N} / \mathrm{rs} \\
121964861\end{array}$ & 16 & $\begin{array}{l}\text { Familial DCM (early death in } n=2 \text { family } \\
\text { members age } 44 \text { and } 21 \text { ) }\end{array}$ & $\begin{array}{l}\text { Impaired cTnC-cTnI and } \\
\text { cTnC-cTnT interactions; } \\
\text { decreased } \mathrm{Ca}^{2+} \text { sensitivity and } \\
\text { ATPase activity }\end{array}$ & {$[61,76]$} \\
\hline
\end{tabular}

Mutations within the same contractile protein can cause HCM, RCM, and DCM, with each cardiomyopathy having its own distinct phenotype. This suggests that different signaling pathways or a graded response within the same pathway is activated, thus producing such variable phenotypes. For example, in transgenic mice with a truncated myosin binding protein- $\mathrm{C}(\mathrm{MyBP}-\mathrm{C})$ protein, there is a graded response with the heterozygous mouse developing HCM and the homozygous developing DCM [77]. In addition, a heterozygous mutation in TnI results in RCM, while the homozygous state results in DCM $[78,79]$. Concurrently, the ratio of mutated to wildtype transcripts is critical in determining severity of DCM [80,81]. On the other hand, molecular signaling studies in DCM and HCM mouse models have reported activation of different signaling pathways suggesting remodeling and profibrotic mechanisms in the two cardiomyopathies are differentially regulated, thus producing two separate phenotypes [82].

Left ventricular systolic function is compromised in DCM, a key symptom for the disease; however, this is usually preserved in HCM. Interestingly, in the latter stages of HCM morphological features resembling DCM occurs in 5-10\% of patients. Patients have a progression to systolic impairment associated with left ventricular remodeling, wall thinning and cavity dilation, thus resembling DCM. Therefore, it is known as the dilated phase of HCM (or D-HCM) [83]. D-HCM is more symptomatic than DCM, where the left atrium is also larger in size with a higher prevalence of atrial fibrillation. This is also combined systolic and diastolic dysfunction. In addition, left ventricular remodeling is not seen in D-HCM and the prognoses is much poorer [83]. Mutations in TNNT2 have been associated with this HCM to D-HCM transition, I79N, R92W, R92Q, R113W, and K273E (Table 2) [71,84-90].

Table 2. Mutations in TNNT2 associated with multiple cardiomyopathies, including hypertrophic cardiomyopathy (HCM), dilated cardiomyopathy (DCM), restrictive cardiomyopathy (RCM), sudden cardiac death (SCD).

\begin{tabular}{cclcc}
\hline Mutation & Exon & \multicolumn{1}{c}{ Clinical Presentation } & Molecular/Cellular Effects & Reference \\
\hline I79N & 8 & $\begin{array}{l}\text { Previously diagnosed in HCM with high incidence of } \\
\text { SCD. Idiopathic DCM (age 68 and 64) }\end{array}$ & $\begin{array}{c}\text { Disrupts the TPM binding } \\
\text { domain of cTnT }\end{array}$ & - \\
\hline R92W & 10 & Progression from HCM to DCM & [86,87] \\
\hline R92Q & 10 & $\begin{array}{l}\text { Mixed phenotype such as mild HCM, DCM with } \\
\text { ventricular dysfunction and noncompaction; severe left } \\
\text { ventricular dysfunction, dyspnea, chest pain and SCD } \\
\text { (and SCD without clinical manifestation) }\end{array}$ & \\
\hline R113W & 10 & $\begin{array}{l}\text { HCM, DCM and RCM } \\
\text { [88,89] }\end{array}$ \\
\hline K273E & 16 & $\begin{array}{l}\text { Transition from FHC to DCM during disease } \\
\text { progression; initially asymmetrical septal hypertrophy } \\
\text { with disease progression to DCM; high incidence of SCD }\end{array}$ & $\begin{array}{c}\text { Decreased ATPase activity and } \\
\text { Ca }{ }^{2+} \text { sensitivity, impaired } \\
\text { force production }\end{array}$ \\
\hline
\end{tabular}




\subsection{Cardiac Troponin T Mutations Relating to Cardiomyopathy in Non-Humans}

As mentioned above, alternative splicing of TNNT2 gives rise to various isoforms that are developmentally regulated. Each isoform varies in structure and function, thus fine-tuning muscle contractility. Alternative spliced isoforms, independent of developmental regulation, have been found in diseased hearts and additionally have been found to cause DCM in turkeys and dogs [92]. A low molecular weight cTnT, due to the exclusion of exon 8 , is expressed in turkeys (often induced by Furazolidone). Exon 8 accounts for 12 amino acids in the protein and expression of this low molecular weight isoform over $30 \%$ in myofibrils results in changes to the conformation and the binding affinity for TnI and TPM, with minor alterations to $\mathrm{Ca}^{2+}$ sensitivity [23].

Exon 7 deletion is observed in canine DCM, where exon 7 is the mammalian equivalent of avian exon 8 . The 12 amino acid deletion in canine (Doberman pincher) showed reduced shortening and re-lengthening of muscle fibers upon stimulation [92]. Exclusion of Exon 6 in guinea pig results in a 25 amino acid residue difference, much larger than that seen in turkey and canine and would suggest significant functional effects [92].

\subsection{Expression, Structure, and Function of Dystrophin}

The dystrophin $(D M D)$ gene codes for the dystrophin protein and at 2.3 megabases long, with 86 exons, it is also one of the largest in the human genome and is situated on the $X$ chromosome [93-95]. The isoforms expressed in cardiac tissue are brain (Dp427 B), muscle (Dp427 M), retinal (Dp260, low expression levels), and G-dystrophin (Dp71) [96,97]. However, the muscle promoter is the main one used for cardiomyocyte expression, with further isoforms produced via splicing alterations such as exon scrambling and exon skipping [98,99].

\subsection{Dystrophin Mutations Relating to Cardiomyopathy in Humans}

Dystrophin has been of interest for many years as mutations have been linked with Duchenne and Becker muscular dystrophies, X-linked DCM and tumor progression and development [99-102]. A basic PubMed search (June 2017) shows 2526 articles with the word 'dystrophin' in the title alone, and the same search in 'Web of Science' shows 3484 results. The Leiden Open Variation Database shows 25,828 confirmed DNA variants and 25,830 RNA and protein variants for human DMD and by 2005 there were 4704 known mutations [103,104]. The UMD-DMD France mutations database reports 2898 fully characterized mutations in dystrophin causing either Becker muscular dystrophy, Duchenne muscular dystrophy, or X-linked DCM. It is estimated that around 33\% of all Becker muscular dystrophy and Duchenne muscular dystrophy causing mutations are spontaneous [105]. Several reports have shown no linkage between the size of deletion or duplication and clinical severity. Clinical outcome does appear to be correlated to whether frameshift or nonsense-mediated RNA decay occurs, indeed deletions of up to $50 \%$ of dystrophin have resulted in Becker muscular dystrophy [106-110]. The mutation types and clinical outcomes were reviewed in detail by Muntoni and colleagues [97].

One of the biggest problems is determining which mutations cause cardiac only symptoms, as even most of the X-linked cardiomyopathy mutations result in some degree of skeletal muscle problems, such as increased plasma creatine levels. In contrast, many of the human and animal cardiomyopathies occur without concomitant skeletal muscle disorders. However, a detailed analysis of the X-linked cardiomyopathy mutations in humans is explored by Ferlini and colleagues [111], but more than 30 mutations in Duchenne muscular dystrophy are thought to cause DCM. There are some common areas which are affected though. There are a group of mutations in the $5^{\prime}$ region that result in altered transcription and splicing. It is thought that the skeletal muscle is able to compensate for this isoform by upregulating other isoforms, but this is not possible in the cardiac tissue [99,112]. Loss of transcript has been shown in a number of cases where a mutation has affected exon 1 resulting in loss of the $M$ isoform $[99,113,114]$. Not all mutations result in full loss of isoforms. One $5^{\prime}$ mutation (duplication of exons 2-7) showed normal transcription in skeletal and cardiac muscle, but a lack of protein expression 
in the heart tissue only [115]. An intron 11 deletion resulted in a lack of the all transcripts in cardiac tissue, whereas skeletal muscle was only partially affected, with normally spliced isoforms able to be expressed [111]. Interestingly, other splice mutations in the $5^{\prime}$ end result in dystrophin expression in both cardiac and skeletal muscle [116]. A mutation in exon 9 also indicated a cardiac specific role for the epitope in question as skeletal effects were not observed [117]. These cardiac affecting mutations highlight the importance of the differing tissue types when considering both transcript and protein levels and their affects in differing regions.

The mutation region also appears to correlate relatively well with clinical severity. In patients with $5^{\prime}$ mutations, the clinical manifestations are usually severe, whereas those in the spectrin-like domain present with a less severe phenotype. It has been hypothesized that the $5^{\prime}$ region mutations may affect enhancers, whereas the spectrin-like domain mutations may only cause loss of a cardiac relevant domain, such as the hinge domain or a regulating sequence. The full mechanisms have yet to be elucidated [111,118].

\subsection{Dystrophin Mutations Relating to Cardiomyopathy in Non-Humans}

Another problem when looking at the murine models is the differing phenotypes between humans and mouse models. In general, the lines created which affected dystrophin only showed very mild phenotypes and usually later on in life [119-121]. The symptoms become more pronounced when using double knockdown models including integrin/dystrophin, utrophin/dystrophin, myoD/dystrophin, and $\delta$-sarcoglycan/dystrophin [122-124]. In addition, these mice frequently are easier to work on, as the cardiomyopathy symptoms occur earlier in life in comparison to dystrophin only models, making the work less expensive and less time consuming [125]. Over 60 models of Duchenne muscular dystrophy have been published and consist of both naturally occurring and laboratory induced animals ranging from the fly, cat, pig, mouse, and dog [126,127]. Despite dystrophin being the primary target gene in many (but not all) of these models and cardiomyopathy being the most common cause of death, very few have DCM as the only symptom, despite so many animals naturally occurring with DCM only in normal populations.

The dog has been a model for Duchenne muscular dystrophy since 1951 [128]. Later groups started investigating the dystrophin gene with over 20 breeds reported as having dystrophin disruption [126]. Research in the 1990s showed that dystrophin was important in canine X-linked muscular dystrophy and dilated cardiomyopathy [129-131]. A point mutation in Golden retrievers in intron 6 (consensus splice acceptor) resulted in a muscular dystrophy like phenotype $[132,133]$. The resulting colonies were used for phenotypic evaluation and genetic therapy trials for a number of years [132,134]. Gene therapy in both mouse models and dogs have shown promising results for delivering mini- or micro-dystrophins delivered via adeno-associated viral vectors especially when immunosuppression is used [135-137]. Although this is more suitable for skeletal muscle, cardiovascular tissue is more complex. A trial using intravenous injection of adeno-associated virus serotype-9 did not show cardiac muscle transduction [138], a serious problem when considering DCM treatment. The first work to look at DCM in three breeds (Doberman Pinschers, Irish Terrier, and German Shorthaired Pointers) indicated that the dystrophin promoter region was not involved in DCM for the first two breeds, but a deletion was observed in the German Shorthaired Pointers. It is worth highlighting that the numbers of Doberman Pinschers and Irish Terriers were relatively small ( $n=9$ and 1 respectively) [129]. Dystrophin mutations are also complex in that mutations are frequently spontaneous. It has been indicated that some breeds and families are more likely to develop DCM [12,139-143]. There is a strong suggestion in the literature for an autosomal inheritance mode in canine breeds such as the Irish Wolfhound, Newfoundland, Great Dane, and Portuguese water dog [139-144]. These indicate that dystrophin, with its one third de novo mutation rate and X-linked DCM, may not play a role in many canine DCM cases, but with around 5\% of human DCM cases presenting as X-linked, this mode is still a possibility in other species [145]. 


\section{Discussion}

Dilated cardiomyopathy has been increasingly of concern in both domestic and commercial animals. The economic loss, food security threats and impact of loss and treatment costs make the condition important to both breeders and owners, the veterinary medicine community, healthcare insurance, pharmaceutical companies, and those involved in the food industry. Advances in genetic testing and more recently gene therapy proof of concept advances are now making mutation detection more accessible and treatment development more promising even in the large dystrophin gene [146-148]. In addition, finding causative mutations enables testing for at risk breeds and species prior to clinical detection and/or symptoms. The decreasing costs of mutation detection and genetic testing tools mean that undertaking this approach in non-human animals are more viable options than a few years ago. Given the size and complexity of dystrophin, investigating the mutation rate will be more expensive and time consuming that the smaller cardiac troponin T. In addition, although many murine and canine dystrophin mutations have shown phenotypic alterations, few are DCM only, which makes it difficult in assessing whether the gene is valuable as a DCM only candidate. With the high de novo rate of mutation and the emerging evidence that DCM in dogs for example is an autosomal inherited disorder in general, it may reduce the possibility that the gene is involved in some species. However, when considering that there are over 4500 mutations described in humans and only 20 in the $\mathrm{dog}$, and that DCM only causing mutations are rare in humans $[149,150]$, it is possible that mutations in non-human animals could cause DCM alone, or DCM accompanied by minimal skeletal disruption.

\section{Conclusions}

Both dystrophin and cardiac troponin T are likely to show regions of interest in relation to DCM given the similarities and conservation between the human and animal sequences. The two genes have differing functions within the cell, but are linked between the species by both sequence and cellular mechanism similarities and by the fact that mutations in each gene have been shown to cause DCM in both humans and non-humans. Many of the cardiac troponin T mutations that cause DCM in human cases result in altered calcium sensitivity, which is also likely to affect animals as it is a common feature of many DCMs $[52,56,151]$. Therefore, despite the aforementioned caveats, both genes make good candidates for undertaking mutation detection studies in species affected by DCM. In the long term this may help with diagnosis and treatment of affected veterinary patients and assist with breeding programs in animals.

Acknowledgments: Funding was provided by The University of Nottingham.

Author Contributions: C.S.R. and J.E. conceived and designed the paper and undertook the literature review, all authors wrote the paper.

Conflicts of Interest: The authors declare no conflict of interest.

\section{References}

1. Wexler, R.K.; Elton, T.; Pleister, A.; Feldman, D. Cardiomyopathy: An overview. Am. Fam. Physician 2009, 79, 778-784. [PubMed]

2. Maron, B.J.; Towbin, J.A.; Thiene, G.; Antzelevitch, C.; Corrado, D.; Arnett, D.; Moss, A.J.; Seidman, C.E.; Young, J.B. Contemporary definitions and classification of the cardiomyopathies: An american heart association scientific statement from the council on clinical cardiology, heart failure and transplantation committee; quality of care and outcomes research and functional genomics and translational biology interdisciplinary working groups; and council on epidemiology and prevention. Circulation 2006, 113, 1807-1816.

3. Wieczorek, D.F.; Jagatheesan, G.; Rajan, S. The role of tropomyosin in heart disease. In Tropomyosin; Gunning, P., Ed.; Springer: New York, NY, USA, 2008; Volume 644, pp. 132-142.

4. Kushwaha, S.S.; Fallon, J.T.; Fuster, V. Restrictive cardiomyopathy. N. Engl. J. Med. 1997, 336, $267-276$. [CrossRef] [PubMed] 
5. Basso, C.; Corrado, D.; Marcus, F.I.; Nava, A.; Thiene, G. Arrhythmogenic right ventricular cardiomyopathy. Lancet 2009, 373, 1289-1300. [CrossRef]

6. Towbin, J.A. Left ventricular noncompaction: A new form of heart failure. Heart Fail. Clin. 2010, 6, 453-469. [CrossRef] [PubMed]

7. Towbin, J.A.; Bowles, N.E. The failing heart. Nature 2002, 415, 227-233. [CrossRef] [PubMed]

8. Braunwald, E. Heart Disease: A Textbook of Cardiovascular Medicine, 8th ed.; Saunders: Phiadelphia, PA, USA, 2008.

9. Fatkin, D. Guidelines for the diagnosis and management of familial dilated cardiomyopathy. Heart Lung Circ. 2011, 20, 691-693. [CrossRef] [PubMed]

10. Cahill, T.J.; Ashrafian, H.; Watkins, H. Genetic cardiomyopathies causing heart failure. Circ. Res. 2013, 113, 660-675. [CrossRef] [PubMed]

11. Fleming, J.M.; Creevy, K.E.; Promislow, D.E. Mortality in north american dogs from 1984 to 2004: An investigation into age-, size-, and breed-related causes of death. J. Vet. Intern. Med. 2011, 25, 187-198. [CrossRef] [PubMed]

12. Egenvall, A.; Bonnett, B.N.; Haggstrom, J. Heart disease as a cause of death in insured Swedish dogs younger than 10 years of age. J. Vet. Intern. Med. 2006, 20, 894-903. [CrossRef] [PubMed]

13. Brownlie, S.E.; Cobb, M.A. Observations on the development of congestive heart failure in Irish wolfhounds with dilated cardiomyopathy. J. Small Anim. Pract. 1999, 40, 371-377. [CrossRef] [PubMed]

14. Simpson, S.; Edwards, J.; Ferguson-Mignan, T.F.; Cobb, M.; Mongan, N.P.; Rutland, C.S. Genetics of Human and Canine Dilated Cardiomyopathy. Int. J. Genom. 2015, 2015, 204823. [CrossRef] [PubMed]

15. Schatzberg, S.J.; Olby, N.J.; Breen, M.; Anderson, L.V.B.; Langford, C.F.; Dickens, H.F.; Wilton, S.D.; Zeiss, C.J.; Binns, M.M.; Kornegay, J.N.; et al. Molecular analysis of a spontaneous dystrophin 'knockout' dog. Neuromuscul. Disord. 1999, 9, 289-295. [CrossRef]

16. Meurs, K.M.; Lahmers, S.; Keene, B.W.; White, S.N.; Oyama, M.A.; Mauceli, E.; Lindblad-Toh, K. A splice site mutation in a gene encoding for PDK4, a mitochondrial protein, is associated with the development of dilated cardiomyopathy in the Doberman pinscher. Hum. Genet. 2012, 131, 1319-1325. [CrossRef] [PubMed]

17. Meurs, K.M.; Stern, J.A.; Sisson, D.D.; Kittleson, M.D.; Cunningham, S.M.; Ames, M.K.; Atkins, C.E.; DeFrancesco, T.; Hodge, T.E.; Keene, B.W.; et al. Association of Dilated Cardiomyopathy with the Striatin Mutation Genotype in Boxer Dogs. J. Vet. Intern. Med. 2013, 27, 1437-1440. [CrossRef] [PubMed]

18. Philipp, U.; Vollmar, A.; Haggstrom, J.; Thomas, A.; Distl, O. Multiple Loci Are Associated with Dilated Cardiomyopathy in Irish Wolfhounds. PLoS ONE 2012, 7, e36691. [CrossRef] [PubMed]

19. Simpson, S.; Edwards, J.; Emes, R.D.; Cobb, M.A.; Mongan, N.P.; Rutland, C.S. A predictive model for canine dilated cardiomyopathy_A meta-analysis of Doberman Pinscher data. PeerJ 2015, 3, e842. [CrossRef] [PubMed]

20. Simpson, S.; Dunning, M.D.; Brownlie, S.; Patel, J.; Godden, M.; Cobb, M.; Mongan, N.P.; Rutland, C.S. Multiple Genetic Associations with Irish Wolfhound Dilated Cardiomyopathy. Biomed. Res. Int. 2016, 2016. [CrossRef] [PubMed]

21. Frame, D.D.; Kelly, E.J.; Van Wettere, A. Dilated Cardiomyopathy in a Rio Grande Wild Turkey (Meleagris gallopavo intermedia) in Southern Utah, USA, 2013. J. Wildl. Dis. 2015, 51, 790-792. [CrossRef] [PubMed]

22. Biesiadecki, B.J.; Schneider, K.L.; Yu, Z.B.; Chong, S.M.; Jin, J.P. An R111C polymorphism in wild turkey cardiac troponin I accompanying the dilated cardiomyopathy-related abnormal splicing variant of cardiac troponin T with potentially compensatory effects. J. Biol. Chem. 2004, 279, 13825-13832. [CrossRef] [PubMed]

23. Biesiadecki, B.J.; Jin, J.P. Exon skipping in cardiac troponin $\mathrm{T}$ of turkeys with inherited dilated cardiomyopathy. J. Biol. Chem. 2002, 277, 18459-18468. [CrossRef] [PubMed]

24. Powers, M.D.; Good, A.L.; Czarnecki, C.M.; Evanson, O.A. Monoamine oxidase inhibition and furazolidone-induced cardiomyopathy in turkey poults. Poult. Sci. 1983, 62, 1850-1855. [CrossRef] [PubMed]

25. Julian, R.J.; Mirsalimi, S.M.; Bagley, L.G.; Squires, E.J. Effect of hypoxia and diet on spontaneous turkey cardiomyopathy (round-heart disease). Avian Dis. 1992, 36, 1043-1047. [CrossRef] [PubMed]

26. Gwathmey, J.K.; Hajjar, R.J. Calcium-activated force in a turkey model of spontaneous dilated cardiomyopathy: Adaptive changes in thin myofilament $\mathrm{Ca}^{2+}$ regulation with resultant implications on contractile performance. J. Mol. Cell. Cardiol. 1992, 24, 1459-1470. [CrossRef]

27. Lin, K.C.; Xu, J.; Kamara, D.; Geng, T.; Gyenai, K.; Reed, K.M.; Smith, E.J. DNA sequence and haplotype variation in two candidate genes for dilated cardiomyopathy in the turkey Meleagris gallopavo. Genome 2007, 50, 463-469. [PubMed] 
28. Breeding, S.W.; McRee, W.A.; Ficken, M.D.; Ferket, P.R. Effect of protein restriction during brooding on spontaneous turkey cardiomyopathy. Avian Dis. 1994, 38, 366-370. [CrossRef] [PubMed]

29. Lin, K.C.; Gyenai, K.; Pyle, R.L.; Geng, T.; Xu, J.; Smith, E.J. Candidate gene expression analysis of toxin-induced dilated cardiomyopathy in the turkey (Meleagris gallopavo). Poult. Sci. 2006, 85, 2216-2221. [CrossRef] [PubMed]

30. Kolb, E. Latest Findings on the Significance and Metabolism of Taurine and on Dysfunctions Caused by Taurine Deficiency (Retinal Degeneration, Cardiomyopathy Etc) in the Cat. Prakt. Tierarzt 1990, 71, 21-24.

31. Pion, P.D.; Kittleson, M.D.; Rogers, Q.R.; Morris, J.G. Myocardial Failure in Cats Associated with Low Plasma Taurine-A Reversible Cardiomyopathy. Science 1987, 237, 764-768. [CrossRef] [PubMed]

32. Pion, P.D.; Kittleson, M.D.; Skiles, M.L.; Rogers, Q.R.; Morris, J.G. Dilated Cardiomyopathy Associated with Taurine Deficiency in the Domestic Cat-Relationship to Diet and Myocardial Taurine Content. Taurine 1992, 315, 63-73.

33. Pion, P.D.; Kittleson, M.D.; Thomas, W.P.; Delellis, L.A.; Rogers, Q.R. Response of Cats with Dilated Cardiomyopathy to Taurine Supplementation. J. Am. Vet. Med. Assoc. 1992, 201, 275-284. [PubMed]

34. Lawler, D.F.; Templeton, A.J.; Monti, K.L. Evidence for Genetic Involvement in Feline Dilated Cardiomyopathy. J. Vet. Intern. Med. 1993, 7, 383-387. [CrossRef] [PubMed]

35. Wilson, F.D.; Magee, D.L.; Jones, K.H.; Baravik-Munsell, E.; Cummings, T.S.; Wills, R.W.; Pace, L.W. Morphometric Documentation of a High Prevalence of Left Ventricular Dilated Cardiomyopathy in Both Clinically Normal and Cyanotic Mature Commercial Broiler Breeder Roosters with Comparisons to Market-Age Broilers. Avian Dis. 2016, 60, 589-595. [CrossRef] [PubMed]

36. Weekes, J.; Wheeler, C.H.; Yan, J.X.; Weil, J.; Eschenhagen, T.; Scholtysik, G.; Dunn, M.J. Bovine dilated cardiomyopathy: Proteomic analysis of an animal model of human dilated cardiomyopathy. Electrophoresis 1999, 20, 898-906. [CrossRef]

37. Nart, P.; Thompson, H.; Barrett, D.C.; Armstrong, S.C.; McPhaden, A.R. Clinical and pathological features of dilated cardiomyopathy in Holstein-Friesian cattle. Vet. Rec. 2004, 155, 355-361. [CrossRef] [PubMed]

38. Simpson, S.; Rutland, P.; Rutland, C.S. Genomic Insights into Cardiomyopathies: A Comparative Cross-Species Review. Vet. Sci. 2017, 1, 19. [CrossRef]

39. Greaser, M.L.; Gergely, J. Reconstitution of troponin activity from three protein components. J. Biol. Chem. 1971, 246, 4226-4233. [PubMed]

40. England, J.; Loughna, S. Heavy and light roles: Myosin in the morphogenesis of the heart. Cell. Mol. Life Sci. 2013, 70, 1-19. [CrossRef] [PubMed]

41. Sehnert, A.J.; Huq, A.; Weinstein, B.M.; Walker, C.; Fishman, M.; Stainier, D.Y.R. Cardiac troponin T is essential in sarcomere assembly and cardiac contractility. Nat. Genet. 2002, 31, 106-110. [CrossRef] [PubMed]

42. Gomes, A.V.; Potter, J.D. Molecular and cellular aspects of troponin cardiomyopathies. Ann. N. Y. Acad. Sci. 2004, 1015, 214-224. [CrossRef] [PubMed]

43. Jin, J.-P.; Zhang, Z.; Bautista, J.A. Isoform Diversity, Regulation, and Functional Adaptation of Troponin and Calponin. Crit. Rev. Eukaryot. Gene Expr. 2008, 18, 93-124. [CrossRef] [PubMed]

44. Perry, S.V. Troponin T: Genetics, properties and function. J. Muscle Res. Cell Motil. 1998, 19, 575-602. [CrossRef] [PubMed]

45. Jin, J.P.; Chong, S.M. Localization of the two tropomyosin-binding sites of troponin T. Arch. Biochem. Biophys. 2010, 500, 144-150. [CrossRef] [PubMed]

46. Pearlstone, J.R.; Smillie, L.B. Binding of troponin-T fragments to several types of tropomyosin. Sensitivity to $\mathrm{Ca}^{2+}$ in the presence of troponin-C. J. Biol. Chem. 1982, 257, 10587-10592. [PubMed]

47. Takeda, S.; Yamashita, A.; Maeda, K.; Maeda, Y. Structure of the core domain of human cardiac troponin in the Ca(2+)-saturated form. Nature 2003, 424, 35-41. [CrossRef] [PubMed]

48. Stefancsik, R.; Jha, P.K.; Sarkar, S. Identification and mutagenesis of a highly conserved domain in troponin T responsible for troponin I binding: Potential role for coiled coil interaction. Proc. Natl. Acad. Sci. USA 1998, 95, 957-962. [CrossRef] [PubMed]

49. Pearlstone, J.R.; Smillie, L.B. Effects of troponin-I plus-C on the binding of troponin T and its fragments to alpha-tropomyosin. $\mathrm{Ca}^{2+}$ sensitivity and cooperativity. J. Biol. Chem. 1983, 258, 2534-2542. [PubMed]

50. Morris, E.P.; Lehrer, S.S. Troponin-tropomyosin interactions. Fluorescence studies of the binding of troponin, troponin T, and chymotryptic troponin T fragments to specifically labeled tropomyosin. Biochemistry 1984, 23, 2214-2220. [CrossRef] [PubMed] 
51. Franklin, A.J.; Baxley, T.; Kobayashi, T.; Chalovich, J.M. The C-terminus of troponin T is essential for maintaining the inactive state of regulated actin. Biophys. J. 2012, 102, 2536-2544. [CrossRef] [PubMed]

52. Hershberger, R.E.; Pinto, J.R.; Parks, S.B.; Kushner, J.D.; Li, D.; Ludwigsen, S.; Cowan, J.; Morales, A.; Parvatiyar, M.S.; Potter, J.D. Clinical and functional characterization of TNNT2 mutations identified in patients with dilated cardiomyopathy. Circ. Cardiovasc. Genet. 2009, 2, 306-313. [CrossRef] [PubMed]

53. Murakami, C.; Nakamura, S.; Kobayashi, M.; Maeda, K.; Irie, W.; Wada, B.; Hayashi, M.; Sasaki, C.; Nakamaru, N.; Furukawa, M.; et al. Analysis of the sarcomere protein gene mutation on cardiomyopathy-Mutations in the cardiac troponin I gene. Legal Med. 2010, 12, 280-283. [CrossRef] [PubMed]

54. Parvatiyar, M.S.; Landstrom, A.P.; Figueiredo-Freitas, C.; Potter, J.D.; Ackerman, M.J.; Pinto, J.R. A Mutation in TNNC1-encoded Cardiac Troponin C, TNNC1-A31S, Predisposes to Hypertrophic Cardiomyopathy and Ventricular Fibrillation. J. Biol. Chem. 2012, 287, 31845-31855. [CrossRef] [PubMed]

55. Chang, A.N.; Parvatiyar, M.S.; Potter, J.D. Troponin and cardiomyopathy. Biochem. Biophys. Res. Commun. 2008, 369, 74-81. [CrossRef] [PubMed]

56. Mirza, M.; Marston, S.; Willott, R.; Ashley, C.; Mogensen, J.; McKenna, W.; Robinson, P.; Redwood, C.; Watkins, H. Dilated Cardiomyopathy Mutations in Three Thin Filament Regulatory Proteins Result in a Common Functional Phenotype. J. Biol. Chem. 2005, 280, 28498-28506. [CrossRef] [PubMed]

57. Lu, Q.W.; Morimoto, S.; Harada, K.; Du, C.K.; Takahashi-Yanaga, F.; Miwa, Y.; Sasaguri, T.; Ohtsuki, I. Cardiac troponin T mutation R141W found in dilated cardiomyopathy stabilizes the troponin T-tropomyosin interaction and causes a $\mathrm{Ca}^{2+}$ desensitization. J. Mol. Cell. Cardiol. 2003, 35, 1421-1427. [CrossRef] [PubMed]

58. Rampersaud, E.; Siegfried, J.D.; Norton, N.; Li, D.; Martin, E.; Hershberger, R.E. Rare variant mutations identified in pediatric patients with dilated cardiomyopathy. Prog. Pediatr. Cardiol. 2011, 31, 39-47. [CrossRef] [PubMed]

59. Zeller, R.; Ivandic, B.T.; Ehlermann, P.; Mucke, O.; Zugck, C.; Remppis, A.; Giannitsis, E.; Katus, H.A.; Weichenhan, D. Large-scale mutation screening in patients with dilated or hypertrophic cardiomyopathy: A pilot study using DGGE. J. Mol. Med. (Berl.) 2006, 84, 682-691. [CrossRef] [PubMed]

60. Hershberger, R.E.; Parks, S.B.; Kushner, J.D.; Li, D.; Ludwigsen, S.; Jakobs, P.; Nauman, D.; Burgess, D.; Partain, J.; Litt, M. Coding sequence mutations identified in MYH7, TNNT2, SCN5A, CSRP3, LBD3, and TCAP from 313 patients with familial or idiopathic dilated cardiomyopathy. Clin. Trans. Sci. 2008, 1, 21-26. [CrossRef] [PubMed]

61. Mogensen, J.; Murphy, R.T.; Shaw, T.; Bahl, A.; Redwood, C.; Watkins, H.; Burke, M.; Elliott, P.M.; McKenna, W.J. Severe disease expression of cardiac troponin $\mathrm{C}$ and $\mathrm{T}$ mutations in patients with idiopathic dilated cardiomyopathy. J. Am. Coll. Cardiol. 2004, 44, 2033-2040. [CrossRef] [PubMed]

62. Lu, Q.W.; Wu, X.Y.; Morimoto, S. Inherited cardiomyopathies caused by troponin mutations. J. Geriatr. Cardiol. 2013, 10, 91-101. [PubMed]

63. Morales, A.; Pinto, J.R.; Siegfried, J.D.; Li, D.; Norton, N.; Hofmeyer, M.; Vallin, M.; Morales, A.R.; Potter, J.D.; Hershberger, R.E. Late onset sporadic dilated cardiomyopathy caused by a cardiac troponin T mutation. Clin. Transl. Sci. 2010, 3, 219-226. [CrossRef] [PubMed]

64. Li, D.; Czernuszewicz, G.Z.; Gonzalez, O.; Tapscott, T.; Karibe, A.; Durand, J.B.; Brugada, R.; Hill, R.; Gregoritch, J.M.; Anderson, J.L.; et al. Novel cardiac troponin T mutation as a cause of familial dilated cardiomyopathy. Circulation 2001, 104, 2188-2193. [CrossRef] [PubMed]

65. Rani, D.S.; Dhandapany, P.S.; Nallari, P.; Narasimhan, C.; Thangaraj, K. A Novel Arginine to Tryptophan (R144W) Mutation in Troponin T (cTnT) Gene in an Indian Multigenerational Family with Dilated Cardiomyopathy (FDCM). PLoS ONE 2014, 9, e101451. [CrossRef] [PubMed]

66. Stefanelli, C.B.; Rosenthal, A.; Borisov, A.B.; Ensing, G.J.; Russell, M.W. Novel troponin T mutation in familial dilated cardiomyopathy with gender-dependant severity. Mol. Genet. Metab. 2004, 83, 188-196. [CrossRef] [PubMed]

67. Jachymova, M.; Muravska, A.; Palecek, T.; Kuchynka, P.; Rehakova, H.; Magage, S.; Kral, A.; Zima, T.; Horky, K.; Linhart, A. Genetic variation screening of TNNT2 gene in a cohort of patients with hypertrophic and dilated cardiomyopathy. Physiol. Res. 2012, 61, 169-175. [PubMed]

68. Van Acker, H.; De Sutter, J.; Vandekerckhove, K.; de Ravel, T.J.; Verhaaren, H.; De Backer, J. Dilated cardiomyopathy caused by a novel TNNT2 mutation-added value of genetic testing in the correct identification of affected subjects. Int. J. Cardiol. 2010, 144, 307-309. [CrossRef] [PubMed] 
69. Davis, J.P.; Tikunova, S.B. Ca(2+) exchange with troponin $\mathrm{C}$ and cardiac muscle dynamics. Cardiovasc. Res. 2008, 77, 619-626. [CrossRef] [PubMed]

70. Sun, N.; Yazawa, M.; Liu, J.; Han, L.; Sanchez-Freire, V.; Abilez, O.J.; Navarrete, E.G.; Hu, S.; Wang, L.; Lee, A.; et al. Patient-specific induced pluripotent stem cells as a model for familial dilated cardiomyopathy. Sci. Transl. Med. 2012, 4, 130ra47. [CrossRef] [PubMed]

71. Venkatraman, G.; Harada, K.; Gomes, A.V.; Kerrick, W.G.; Potter, J.D. Different functional properties of troponin T mutants that cause dilated cardiomyopathy. J. Biol. Chem. 2003, 278, 41670-41676. [CrossRef] [PubMed]

72. Daehmlow, S.; Erdmann, J.; Knueppel, T.; Gille, C.; Froemmel, C.; Hummel, M.; Hetzer, R.; Regitz-Zagrosek, V. Novel mutations in sarcomeric protein genes in dilated cardiomyopathy. Biochem. Biophys. Res. Commun. 2002, 298, 116-120. [CrossRef]

73. Kamisago, M.; Sharma, S.D.; DePalma, S.R.; Solomon, S.; Sharma, P.; McDonough, B.; Smoot, L.; Mullen, M.P.; Woolf, P.K.; Wigle, E.D.; et al. Mutations in Sarcomere Protein Genes as a Cause of Dilated Cardiomyopathy. N. Engl. J. Med. 2000, 343, 1688-1696. [CrossRef] [PubMed]

74. Inoue, T.; Kobirumaki-Shimozawa, F.; Kagemoto, T.; Fujii, T.; Terui, T.; Kusakari, Y.; Hongo, K.; Morimoto, S.; Ohtsuki, I.; Hashimoto, K.; et al. Depressed Frank-Starling mechanism in the left ventricular muscle of the knock-in mouse model of dilated cardiomyopathy with troponin T deletion mutation DeltaK210. J. Mol. Cell. Cardiol. 2013, 63, 69-78. [CrossRef] [PubMed]

75. Watkins, H.; McKenna, W.J.; Thierfelder, L.; Suk, H.J.; Anan, R.; O’Donoghue, A.; Spirito, P.; Matsumori, A.; Moravec, C.S.; Seidman, J.G.; et al. Mutations in the Genes for Cardiac Troponin T and $\alpha$-Tropomyosin in Hypertrophic Cardiomyopathy. N. Engl. J. Med. 1995, 332, 1058-1065. [CrossRef] [PubMed]

76. Robinson, P.; Griffiths, P.J.; Watkins, H.; Redwood, C.S. Dilated and hypertrophic cardiomyopathy mutations in troponin and alpha-tropomyosin have opposing effects on the calcium affinity of cardiac thin filaments. Circ. Res. 2007, 101, 1266-1273. [CrossRef] [PubMed]

77. McConnell, B.K.; Jones, K.A.; Fatkin, D.; Arroyo, L.H.; Lee, R.T.; Aristizabal, O.; Turnbull, D.H.; Georgakopoulos, D.; Kass, D.; Bond, M.; et al. Dilated cardiomyopathy in homozygous myosin-binding protein C mutant mice. J. Clin. Investig. 1999, 104, 1235-1244. [CrossRef] [PubMed]

78. Murphy, R.T.; Mogensen, J.; Shaw, A.; Kubo, T.; Hughes, S.; McKenna, W.J. Novel mutation in cardiac troponin I in recessive idiopathic dilated cardiomyopathy. Lancet 2004, 363, 371-372. [CrossRef]

79. Mogensen, J.; Kubo, T.; Duque, M.; Uribe, W.; Shaw, A.; Murphy, R.; Gimeno, J.R.; Elliott, P.; McKenna, W.J. Idiopathic restrictive cardiomyopathy is part of the clinical expression of cardiac troponin I mutations. J. Clin. Investig. 2003, 111, 209-216. [CrossRef] [PubMed]

80. Ahmad, F.; Banerjee, S.K.; Lage, M.L.; Huang, X.N.; Smith, S.H.; Saba, S.; Rager, J.; Conner, D.A.; Janczewski, A.M.; Tobita, K.; et al. The Role of Cardiac Troponin T Quantity and Function in Cardiac Development and Dilated Cardiomyopathy. PLoS ONE 2008, 3, e2642. [CrossRef] [PubMed]

81. Ramratnam, M.; Salama, G.; Sharma, R.K.; Wang, D.W.; Smith, S.H.; Banerjee, S.K.; Huang, X.N.; Gifford, L.M.; Pruce, M.L.; Gabris, B.E.; et al. Gene-Targeted Mice with the Human Troponin T R141W Mutation Develop Dilated Cardiomyopathy with Calcium Desensitization. PLoS ONE 2016, 11, e0167681. [CrossRef] [PubMed]

82. Burke, M.A.; Chang, S.; Wakimoto, H.; Gorham, J.M.; Conner, D.A.; Christodoulou, D.C.; Parfenov, M.G.; DePalma, S.R.; Eminaga, S.; Konno, T.; et al. Molecular profiling of dilated cardiomyopathy that progresses to heart failure. JCI Insight 2016, 1. [CrossRef] [PubMed]

83. Hamada, T.; Kubo, T.; Kitaoka, H.; Hirota, T.; Hoshikawa, E.; Hayato, K.; Shimizu, Y.; Okawa, M.; Yamasaki, N.; Matsumura, Y.; et al. Clinical features of the dilated phase of hypertrophic cardiomyopathy in comparison with those of dilated cardiomyopathy. Clin. Cardiol. 2010, 33, E24-E28. [CrossRef] [PubMed]

84. Fujino, N.; Shimizu, M.; Ino, H.; Okeie, K.; Yamaguchi, M.; Yasuda, T.; Kokado, H.; Mabuchi, H. Cardiac troponin T Arg92 Trp mutation and progression from hypertrophic to dilated cardiomyopathy. Clin. Cardiol. 2001, 24, 397-402. [CrossRef] [PubMed]

85. Fujino, N.; Shimizu, M.; Ino, H.; Yamaguchi, M.; Yasuda, T.; Nagata, M.; Konno, T.; Mabuchi, H. A novel mutation Lys273Glu in the cardiac troponin $\mathrm{T}$ gene shows high degree of penetrance and transition from hypertrophic to dilated cardiomyopathy. Am. J. Cardiol. 2002, 89, 29-33. [CrossRef] 
86. Thierfelder, L.; Watkins, H.; MacRae, C.; Lamas, R.; McKenna, W.; Vosberg, H.P.; Seidman, J.G.; Seidman, C.E. Alpha-tropomyosin and cardiac troponin $\mathrm{T}$ mutations cause familial hypertrophic cardiomyopathy: A disease of the sarcomere. Cell 1994, 77, 701-712. [CrossRef]

87. Menon, S.C.; Michels, V.V.; Pellikka, P.A.; Ballew, J.D.; Karst, M.L.; Herron, K.J.; Nelson, S.M.; Rodeheffer, R.J.; Olson, T.M. Cardiac troponin T mutation in familial cardiomyopathy with variable remodeling and restrictive physiology. Clin. Genet. 2008, 74, 445-454. [CrossRef] [PubMed]

88. Ripoll-Vera, T.; Gamez, J.M.; Govea, N.; Gomez, Y.; Nunez, J.; Socias, L.; Escandell, A.; Rosell, J. Clinical and Prognostic Profiles of Cardiomyopathies Caused by Mutations in the Troponin T Gene. Rev. Esp. Cardiol. (Engl. Ed.) 2016, 69, 149-158. [CrossRef] [PubMed]

89. Robinson, P.; Mirza, M.; Knott, A.; Abdulrazzak, H.; Willott, R.; Marston, S.; Watkins, H.; Redwood, C. Alterations in thin filament regulation induced by a human cardiac troponin $\mathrm{T}$ mutant that causes dilated cardiomyopathy are distinct from those induced by troponin T mutants that cause hypertrophic cardiomyopathy. J. Biol. Chem. 2002, 277, 40710-40716. [CrossRef] [PubMed]

90. Jaquet, K.; Mugge, A. Consequences of Mutations in Genes Encoding Cardiac Troponin C, T and I-Molecular Insights and Cardiomyopathies; Veselka, J., Ed.; Basic Research to Clincal Management; InTech: Rijeka, Croatia, 2012.

91. Na, I.; Kong, M.J.; Straight, S.; Pinto, J.R.; Uversky, V.N. Troponins, intrinsic disorder, and cardiomyopathy. Biol. Chem. 2016, 397, 731-751. [CrossRef] [PubMed]

92. Biesiadecki, B.J.; Elder, B.D.; Yu, Z.-B.; Jin, J.-P. Cardiac Troponin T Variants Produced by Aberrant Splicing of Multiple Exons in Animals with High Instances of Dilated Cardiomyopathy. J. Biol. Chem. 2002, 277, 50275-50285. [CrossRef] [PubMed]

93. Kunkel, L.M.; Beggs, A.H.; Hoffman, E.P. Molecular genetics of Duchenne and Becker muscular dystrophy: Emphasis on improved diagnosis. Clin. Chem. 1989, 35 (Suppl. 7), B21-B24. [PubMed]

94. Mandel, J.L. Dystrophin. The gene and its product. Nature 1989, 339, 584-586. [PubMed]

95. Manole, E. The dystrophin gene and its product-A view. Rom. J. Neurol. Psychiatry 1995, 33, 109-119. [PubMed]

96. Surono, A.; Barnea, E.; Levy, Z.; Neuman, S.; Yaffe, D.; Nudel, U. Circular dystrophin RNAs consisting of exons that were skipped by alternative splicing. Hum. Mol. Genet. 1999, 8, 493-500. [CrossRef] [PubMed]

97. Muntoni, F.; Torelli, S.; Ferlini, A. Transcription of the dystrophin gene in normal tissues and in skeletal muscle of a family with X-linked dilated cardiomyopathy. Am. J. Hum. Genet. 1995, 56, 151-157. [PubMed]

98. Bar, S.; Takeshima, Y.; Wibawa, T.; Ikezawa, M.; Nonaka, I.; Matsuo, M. A novel product of the Duchenne muscular dystrophy gene which greatly differs from the known isoforms in its structure and tissue distribution. Biochem. J. 1990, 272, 557-560. [CrossRef] [PubMed]

99. Muntoni, F.; Torelli, S.; Ferlini, A. Dystrophin and mutations: One gene, several proteins, multiple phenotypes. Lancet Neurol. 2003, 2, 731-740. [CrossRef]

100. Wang, Y.X.; Marino-Enriquez, A.; Bennett, R.R.; Zhu, M.J.; Shen, Y.P.; Eilers, G.; Lee, J.C.; Henze, J.; Fletcher, B.S.; Gu, Z.Z.; et al. Dystrophin is a tumor suppressor in human cancers with myogenic programs. Nat. Genet. 2014, 46, 601-606. [CrossRef] [PubMed]

101. Korner, H.; Epanchintsev, A.; Berking, C.; Schuler-Thurner, B.; Speicher, M.R.; Menssen, A.; Hermeking, H. Digital karyotyping reveals frequent inactivation of the Dystrophin/DMD gene in malignant melanoma. Cell Cycle 2007, 6, 189-198. [CrossRef] [PubMed]

102. Monaco, A.P.; Neve, R.L.; Collettifeener, C.; Bertelson, C.J.; Kurnit, D.M.; Kunkel, L.M. Isolation of Candidate Cdnas for Portions of the Duchenne Muscular-Dystrophy Gene. Nature 1986, 323, 646-650. [CrossRef] [PubMed]

103. Aartsma-Rus, A.; Van Deutekom, J.C.T.; Fokkema, I.F.; Van Ommen, G.J.B.; Den Dunnen, J.T. Entries in the Leiden Duchenne muscular dystrophy mutation database: An overview of mutation types and paradoxical cases that confirm the reading-frame rule. Muscle Nerve 2006, 34, 135-144. [CrossRef] [PubMed]

104. Fokkema, I.F.A.C.; den Dunnen, J.T.; Taschner, P.E.M. LOVD: Easy creation of a locus-specific sequence variation database using an "LSDB-in-a-Box" approach. Hum. Mutat. 2005, 26, 63-68. [CrossRef] [PubMed]

105. Laing, N.G. Molecular Genetics and Genetic Couselling for Duchenne/Becker Muscular Dystrophy, in Molecular and Cell Biology of Muscular Dystrophy; Partridge, T., Ed.; Chapman \& Hall: London, UK, 1993; pp. 37-84.

106. Love, D.R.; Flint, T.J.; Genet, S.A.; Middletonprice, H.R.; Davies, K.E. Becker Muscular-Dystrophy Patient with a Large Intragenic Dystrophin Deletion-Implications for Functional Minigenes and Gene-Therapy. J. Med. Genet. 1991, 28, 860-864. [CrossRef] [PubMed] 
107. England, S.B.; Nicholson, L.V.B.; Johnson, M.A.; Forrest, S.M.; Love, D.R.; Zubrzyckagaarn, E.E.; Bulman, D.E.; Harris, J.B.; Davies, K.E. Very Mild Muscular-Dystrophy Associated with the Deletion of 46-Percent of Dystrophin. Nature 1990, 343, 180-182. [CrossRef] [PubMed]

108. Love, D.R.; Flint, T.J.; Marsden, R.F.; Bloomfield, J.F.; Daniels, R.J.; Forrest, S.M.; Gabrielli, O.; Giorgi, P.; Novelli, G.; Davies, K.E. Characterization of Deletions in the Dystrophin Gene Giving Mild Phenotypes. Am. J. Med. Genet. 1990, 37, 136-142. [CrossRef] [PubMed]

109. Monaco, A.P.; ertelson, C.J.; Liechti-Gallati, S.; Moser, H.; Kunkel, L.M. An Explanation for the Phenotypic Differences between Patients Bearing Partial Deletions of the DMD Locus. Genomics 1988, 2, 90-95. [CrossRef]

110. Kerr, T.P.; Sewry, C.A.; Robb, S.A.; Roberts, R.G. Long mutant dystrophins and variable phenotypes: Evasion of nonsense-mediated decay? Hum. Genet. 2001, 109, 402-407. [CrossRef] [PubMed]

111. Ferlini, A.; Sewry, C.; Melis, M.A.; Mateddu, A.; Muntoni, F. X-linked dilated cardiomyopathy and the dystrophin gene. Neuromuscul. Disord. 1999, 9, 339-346. [CrossRef]

112. Feng, J.; Yan, J.Y.; Buzin, C.H.; Sommer, S.S.; Towbin, J.A. Comprehensive mutation scanning of the dystrophin gene in patients with nonsyndromic X-linked dilated cardiomyopathy. J. Am. Coll. Cardiol. 2002, 40, 1120-1124. [CrossRef]

113. Milasin, J.; Muntoni, F.; Severini, G.M.; Bartoloni, L.; Vatta, M.; Krajinovic, M.; Mateddu, A.; Angelini, C.; Camerini, F.; Falaschi, A.; et al. A point mutation in the $5^{\prime}$ splice site of the dystrophin gene first intron responsible for X-linked dilated cardiomyopathy. Hum. Mol. Genet. 1996, 5, 73-79. [CrossRef] [PubMed]

114. Nakamura, A.; Ikeda, S.; Yazaki, M.; Yoshida, K.; Kobayashi, O.; Yanagisawa, N.; Takeda, S. Up-regulation of the brain and Purkinje-cell forms of dystrophin transcripts, in Becker muscular dystrophy. Am. J. Hum. Genet. 1997, 60, 1555-1558. [CrossRef]

115. Bies, R.D.; Maeda, M.; Roberds, S.L.; Holder, E.; Bohlmeyer, T.; Young, J.B.; Campbell, K.P. A 5' dystrophin duplication mutation causes membrane deficiency of alpha-dystroglycan in a family with X-linked cardiomyopathy. J. Mol. Cell. Cardiol. 1997, 29, 3175-3188. [CrossRef] [PubMed]

116. Franz, W.M.; Cremer, M.; Herrmann, R.; Grunig, E.; Fogel, W.; Scheffold, T.; Goebel, H.H.; Kircheisen, R.; Kubler, W.; Voit, T.; et al. X-linked dilated cardiomyopathy. Novel mutation of the dystrophin gene. Ann. N. Y. Acad. Sci. 1995, 752, 470-491. [CrossRef] [PubMed]

117. Ortiz-Lopez, R.; Li, H.; Su, J.; Goytia, V.; Towbin, J.A. Evidence for a dystrophin missense mutation as a cause of X-linked dilated cardiomyopathy. Circulation 1997, 95, 2434-2440. [CrossRef] [PubMed]

118. Winder, S.J.; Gibson, T.J.; Kendrick-Jones, J. Dystrophin and utrophin: The missing links! FEBS Lett. 1995, 369, 27-33. [CrossRef]

119. Cullen, M.J.; Jaros, E. Ultrastructure of the Skeletal-Muscle in the X-Chromosome-Linked Dystrophic (Mdx) Mous-Comparison with Duchenne Muscular-Dystrophy. Acta Neuropathol. 1988, 77, 69-81. [CrossRef] [PubMed]

120. Bulfield, G.; Siller, W.G.; Wight, P.A.L.; Moore, K.J. X-Chromosome-Linked Muscular-Dystrophy (Mdx) in the Mouse. Proc. Natl. Acad. Sci. USA 1984, 81, 1189-1192. [CrossRef]

121. Chapman, V.M.; Miller, D.R.; Armstrong, D.; Caskey, C.T. Recovery of Induced Mutations for X-Chromosome-Linked Muscular-Dystrophy in Mice. Proc. Natl. Acad. Sci. USA 1989, 86, 1292-1296. [CrossRef] [PubMed]

122. Li, D.J.; Long, C.; Yue, Y.P.; Duan, D.S. Sub-physiological sarcoglycan expression contributes to compensatory muscle protection in mdx mice. Hum. Mol. Genet. 2009, 18, 1209-1220. [CrossRef] [PubMed]

123. Deconinck, A.E.; Rafael, J.A.; Skinner, J.A.; Brown, S.C.; Potter, A.C.; Metzinger, L.; Watt, D.J.; Dickson, J.G.; Tinsley, J.M.; Davies, K.E. Utrophin-dystrophin-deficient mice as a model for Duchenne muscular dystrophy. Cell 1997, 90, 717-727. [CrossRef]

124. Rooney, J.E.; Welser, J.V.; Dechert, M.A.; Flintoff-Dye, N.L.; Kaufman, S.J.; Burkin, D.J. Severe muscular dystrophy in mice that lack dystrophin and alpha 7 integrin. J. Cell Sci. 2006, 119, 2185-2195. [CrossRef] [PubMed]

125. Chun, J.L.; O’Brien, R.; Berry, S.E. Cardiac dysfunction and pathology in the dystrophin and utrophin-deficient mouse during development of dilated cardiomyopathy. Neuromuscul. Disord. 2012, 22, 368-379. [CrossRef] [PubMed]

126. McGreevy, J.W.; Hakim, C.H.; McIntosh, M.A.; Duan, D.S. Animal models of Duchenne muscular dystrophy: From basic mechanisms to gene therapy. Dis. Model. Mech. 2015, 8, 195-213. [CrossRef] [PubMed] 
127. Taghli-Lamallem, O.; Akasaka, T.; Hogg, G.; Nudel, U.; Yaffe, D.; Chamberlain, J.S.; Ocorr, K.; Bodmer, R. Dystrophin deficiency in Drosophila reduces lifespan and causes a dilated cardiomyopathy phenotype. Aging Cell 2008, 7, 237-249. [CrossRef] [PubMed]

128. Innes, J.R. Myopathies in animals; a record of some cases including progressive muscular dystrophy (pseudo-hypertrophic) (dog), "weisses Fleisch" (lamb), neuropathic muscular atrophy (sheep) and lymphocytic/histiocytic myositis, neuritis, radiculitis (dog). Br. Vet. J. 1951, 107, 131-143. [PubMed]

129. Schatzberg, S.; Olby, N.; Steingold, S.; Keene, B.; Atkins, C.; Meurs, K.; Solomon, G.; Goedegebuure, S.A.; Wilton, S.; Sharp, N. A polymerase chain reaction screening strategy for the promoter of the canine dystrophin gene. Am. J. Vet. Res. 1999, 60, 1040-1046. [PubMed]

130. Sewry, C.A.; Wilson, L.A.; Dux, L.; Dubowitz, V.; Cooper, B.J. Experimental regeneration in canine muscular dystrophy-1. Immunocytochemical evaluation of dystrophin and beta-spectrin expression. Neuromuscul. Disord. 1992, 2, 331-342. [CrossRef]

131. Cooper, B.J.; Gallagher, E.A.; Smith, C.A.; Valentine, B.A.; Winand, N.J. Mosaic expression of dystrophin in carriers of canine X-linked muscular dystrophy. Lab. Investig. 1990, 62, 171-178. [PubMed]

132. Howell, J.M.; Fletcher, S.; Kakulas, B.A.; OHara, M.; Lochmuller, H.; Karpati, G. Use of the dog model for Duchenne muscular dystrophy in gene therapy trials. Neuromuscul. Disord. 1997, 7, 325-328. [CrossRef]

133. Valentine, B.A.; Chandler, S.K.; Cummings, J.F.; Cooper, B.J. In vitro characteristics of normal and dystrophic skeletal muscle from dogs. Am. J. Vet. Res. 1991, 52, 104-107. [PubMed]

134. Cooper, B.J. The Xmd Dog-Molecular and Phenotypic Characteristics. In Duchenne Muscular Dystrophy; Animal Models and Genetic Manipulations; Raven Press: New York, NY, USA, 1992; pp. 109-111.

135. Wang, Z.; Storb, R.; Halbert, C.L.; Banks, G.B.; Butts, T.M.; Finn, E.E.; Allen, J.M.; Miller, A.D.; Chamberlain, J.S.; Tapscott, S.J. Successful regional delivery and long-term expression of a dystrophin gene in canine muscular dystrophy: A preclinical model for human therapies. Mol. Ther. 2012, 20, 1501-1507. [CrossRef] [PubMed]

136. Wang, Z.J.; Chamberlain, J.S.; Tapscott, S.J.; Storb, R. Gene Therapy in Large Animal Models of Muscular Dystrophy. Ilar J. 2009, 50, 187-198. [CrossRef] [PubMed]

137. Gregorevic, P.; Blankinship, M.J.; Allen, J.M.; Crawford, R.W.; Meuse, L.; Miller, D.G.; Russell, D.W.; Chamberlain, J.S. Systemic delivery of genes to striated muscles using adeno-associated viral vectors. Nat. Med. 2004, 10, 828-834. [CrossRef] [PubMed]

138. Yue, Y.P.; Ghosh, A.; Long, C.; Bostick, B.; Smith, B.F.; Kornegay, J.N.; Duan, D.S. A Single Intravenous Injection of Adeno-associated Virus Serotype-9 Leads to Whole Body Skeletal Muscle Transduction in Dogs. Mol. Ther. 2008, 16, 1944-1952. [CrossRef] [PubMed]

139. Cobb, M.A.; Brownlie, S.E.; Pidduck, H.G.; Batt, R.M. Evidence for genetic involvement in dilated cardiomyopathy in the Irish Wolfhound. In Proceedings of the Annual Congress of BSAVA, Birmingham, UK, 15-18 September 1996.

140. Dukes McEwan, J. Dilated cardiomyopathy in Newfoundlands. In Proceedings of the Veterinary Cardiovascular Society Meeting, Birmingham, UK, 1997.

141. Tidholm, A.; Haggstrom, J.; Borgarelli, M.; Tarducci, A. Canine idiopathic dilated cardiomyopathy. Part I: Aetiology, clinical characteristics, epidemiology and pathology. Vet. J. 2001, 162, 92-107. [PubMed]

142. Meurs, K.R. Insights into the hereditability of canine cardiomyopathy. Vet. Clin. N. Am.-Small Anim. Pract. 1998, 28, 1449-1457. [CrossRef]

143. Dambach, D.M.; Lannon, A.; Sleeper, M.M.; Buchanan, J. Familial dilated cardiomyopathy of young Portuguese Water Dogs. J. Vet. Intern. Med. 1999, 13, 65-71. [CrossRef] [PubMed]

144. Meurs, K.M.; Miller, M.W.; Wright, N.A. Clinical features of dilated cardiomyopathy in Great Danes and results of a pedigree analysis: 17 cases (1990-2000). J. Am. Vet. Med. Assoc. 2001, 218, 729-732. [CrossRef] [PubMed]

145. Cohen, N.; Muntoni, F. Multiple pathogenetic mechanisms in X linked dilated cardiomyopathy. Heart 2004, 90, 835-841. [CrossRef] [PubMed]

146. Counsell, J.R.; Asgarian, Z.; Meng, J.; Ferrer, V.; Vink, C.A.; Howe, S.J.; Waddington, S.N.; Thrasher, A.J.; Muntoni, F.; Morgan, J.E.; et al. Lentiviral vectors can be used for full-length dystrophin gene therapy. Sci. Rep. 2017, 7, 44775. [CrossRef] [PubMed] 
147. Farruggio, A.P.; Bhakta, M.S.; du Bois, H.; Ma, J.; Calos, M.P. Genomic integration of the full-length dystrophin coding sequence in Duchenne muscular dystrophy induced pluripotent stem cells. Biotechnol. J. 2017, 12. [CrossRef] [PubMed]

148. Lu-Nguyen, N.; Malerba, A.; Popplewell, L.; Schnell, F.; Hanson, G.; Dickson, G. Systemic Antisense Therapeutics for Dystrophin and Myostatin Exon Splice Modulation Improve Muscle Pathology of Adult mdx Mice. Mol. Ther. Nucleic Acids 2017, 6, 15-28. [CrossRef] [PubMed]

149. Shimizu, M.; Ino, H.; Yasuda, T.; Fujino, N.; Uchiyama, K.; Mabuchi, T.; Konno, T.; Kaneda, T.; Fujita, T.; Masuta, E.; et al. Gene mutations in adult Japanese patients with dilated cardiomyopathy. Circ. J. 2005, 69, 150-153. [CrossRef] [PubMed]

150. Arbustini, E.; Diegoli, M.; Morbini, P.; Dal Bello, B.; Banchieri, N.; Pilotto, A.; Magani, F.; Grasso, M.; Narula, J.; Gavazzi, A.; et al. Prevalence and characteristics of dystrophin defects in adult male patients with dilated cardiomyopathy. J. Am. Coll. Cardiol. 2000, 35, 1760-1768. [CrossRef]

151. Deftereos, S.; Papoutsidakis, N.; Giannopoulos, G.; Angelidis, C.; Raisakis, K.; Bouras, G.; Davlouros, P.; Panagopoulou, V.; Goudevenos, J.; Cleman, M.W.; et al. Calcium Ions in Inherited Cardiomyopathies. Med. Chem. 2016, 12, 139-150. [CrossRef] [PubMed]

(C) 2017 by the authors. Licensee MDPI, Basel, Switzerland. This article is an open access article distributed under the terms and conditions of the Creative Commons Attribution (CC BY) license (http://creativecommons.org/licenses/by/4.0/). 